\title{
Diversity of the composition and content of soluble carbohydrates in seeds of the genus Vicia (Leguminosae)
}

\author{
Lesław Bernard Lahuta • Monika Ciak • Wojciech Rybiński • Jan Bocianowski • \\ Andreas Börner
}

Received: 15 March 2017/Accepted: 14 August 2017/Published online: 30 August 2017

(C) The Author(s) 2017. This article is an open access publication

\begin{abstract}
Low molecular weight carbohydrates of seeds of 10 species of Vicia, namely: V. angustifolia, $V$. articulata, V. cordata, V. ervilia, V. johannis, $V$. macrocarpa, V. monantha, V. narbonensis, V. pannonica and $V$. sativa were analyzed by the high resolution gas chromatography method. Seeds of the investigated species contain common (glucose, fructose, myo-inositol, sucrose, galactinol, di-galactosyl myo-inositol and raffinose family oligosaccharidesRFOs) and species-specific carbohydrates (D-pinitol
\end{abstract}

Electronic supplementary material The online version of this article (doi:10.1007/s10722-017-0552-y) contains supplementary material, which is available to authorized users.

L. B. Lahuta $(\bowtie) \cdot$ M. Ciak

Department of Plant Physiology, Genetics and

Biotechnology, University of Warmia and Mazury in

Olsztyn, Oczapowskiego Street 1A/103, 10-719 Olsztyn,

Poland

e-mail: lahuta@uwm.edu.pl

W. Rybiński

Department of Genomics, Institute of Plant Genetics

Polish Academy of Science, Strzeszyńska 34,

60-101 Poznan, Poland

J. Bocianowski

Department of Mathematical and Statistical Methods, Poznań University of Life Sciences, Wojska Polskiego 28, 60-637 Poznan, Poland

\section{A. Börner}

Leibniz Institute of Plant Genetics and Crop Plant

Research, 06466 Gatersleben, Germany and its $\alpha$-D-galactosides-in $V$. articulata, $V$. monantha and $V$. pannonica or D-ononitol and its galactoside-in V. ervilia). Among the species containing in seeds RFOs as the main $\alpha$-D-galactosides ( $V$. angustifolia, $V$. cordata, $V$. johanensis, V. macrocarpa, V. narbonensis and $V$. sativa), an additional subgroup can be separated, which contains a set of unknown compounds (found in $V$. angustifolia, $V$. cordata and $V$. macrocarpa). Moreover, several other unidentified carbohydrate-containing compounds were detected exclusively in seeds of $V$. ervilia. The concentrations of total soluble carbohydrates (TSCs), including sugars, RFOs, cyclitols and galactosyl cyclitols and unknown compounds, in seeds differ significantly $(P<0.05)$ among the species. RFOs and sucrose are the main fractions in TSCs, with the exception of $V$. pannonica seeds, containing more galactosyl pinitols, and $V$. ervilia, in which unknown compounds account for $50 \%$ of TSCs. In V. ervilia RFOs occur at the lowest concentration $\left(9.32 \mathrm{mg} \mathrm{g}^{-1}\right.$ seeds), and the concentration of DGMI (di-galactosyl myo-inositol) is comparable with that of RFOs, which is unusual among all the investigated Vicia species.

Keywords Vicia . Seeds · Chemotaxonomy · Carbohydrate $\cdot$ Raffinose oligosaccharides $\cdot$ Pinitol

\section{Introduction}

The genus Vicia L. comprises about 160 annual and perennial species, which are distributed in Europe, 
Asia, Americas and tropical East Africa (Schaefer et al. 2012). A few important annual species, such as $V$. narbonensis L. (narbon vetch), V. sativa L. subsp. sativa (common vetch), V. ervilia (L.) Willd. (bitter vetch) and $V$. villosa Roth subsp. dasycarpa (hairypod vetch) are grown for livestock feed in non-tropical dry areas. The grains of these vetches can be used as less costly sources of proteins and energy for ruminants and non-ruminants. However, seeds of some Vicia species contain also toxins and antinutritional compounds, restricting their use as food and feed (Enneking and Wink 2000). Moreover, the presence of raffinose family oligosaccharides (RFOs: including raffinose, stachyose, verbascose, ajugose), ubiquitous for seeds of all legumes (Obendorf and Górecki 2012), is an additional factor decreasing the use of vetch seeds by monogastric animals and humans. RFOs are $\alpha$-D-galactosides of sucrose, containing 1-4 units of galactose linked by $\alpha-1,6$ linkages. They are not digested in the upper part of the gastrointestinal tract, due to the absence of endogenous $\alpha$-D-galactosidase, and are therefore available for bacterial fermentation in the colon, causing flatulence and digestive discomfort (Martínez-Villaluenga et al. 2008). In seeds of some legumes, including several Vicia species, beside RFOs, $\alpha$-D-galactosides of cyclitols (galactosyl cyclitols, GalCs) are present (Yasui and Ohashi 1990), whose flatulent potential seems to be lower than RFOs. The physiological effects of GalCs are not known. However, cyclitols (myo-inositol, D-chiro-inositol, Dpinitol), released during GalCs hydrolysis in the digestive tract, indicate some health benefit properties (insulin-mimetic, antioxidative, anti-inflammatory and anticancer activity) and can be used as diet supplements with therapeutic properties (Croze and Soulage 2013). Thus, legume seeds can be used not only as foodstuff, but also as a source of healthpromoting cyclitols.

The content and composition of $\alpha$-D-galactosides in seeds was characterized in detail in major legume crops: soybean (Glycine max [L.] Merr.), pea (Pisum sativum L.), bean (Phaseolus vulgaris L.), lentil (Lens culinaris L.) and chickpea (Cicer arietinum L.). The concentration of RFOs is within the range of $2-12 \%$ of dry matter and stachyose or verbascose are the prevalent oligosaccharides in seeds (Guillon and Champ 2002). The concentration of GalCs occurring in seeds of lentil, chickpea, soybean and lupin (Lupinus L.) is lower (up to $3-4 \%$, in chickpea) than that of RFOs (up to 12\%, in lupin, Gulewicz et al. 2014). Galactosyl pinitols (ciceritol and galactopinitol A) predominate among GalCs (Obendorf et al. 2012).

Infrageneric variation of RFOs and GalCs in seeds of Vicia genus was characterized by Yasui et al. (1987). In the chemotaxonomic studies, these authors analyzed 29 species, including 19 accessions of common vetch and 3 accessions of narbon vetch. In the seeds of the two latter species, RFOs are the only $\alpha$-D-galactosides, and verbascose was the predominant oligosaccharide (1.2-2.0\% of dry mass). Verbascose is also a major oligosaccharide in bitter vetch (Muzquiz et al. 2012). Seeds of few other Vicia species accumulate considerable amounts of D-pinitol and its galactosides (Yasui et al. 1987; Lahuta et al. 2005a). The higher concentration of galactosyl pinitols than RFOs in seeds is a unique feature and has been found only in the subgenus Cracca, in seeds of V. villosa Roth, V. cracca L. (Yasui et al. 1987; Lahuta et al. 2005a; Lahuta 2006) and V. tenuifolia Roth (Lahuta et al. 2010a). The characterization of low molecular weight carbohydrates in seeds of legumes from different taxa allowed Yasui and Ohashi (1990) to conclude that the accumulation of RFOs is a primary evolutionary attribute of legumes, whereas the synthesis of myo-inositol methyl derivatives: D-ononitol, D-pinitol and D-bornesitol and their $\alpha$-D-galactosides, is a secondary trait. The confirmation of this hypothesis can be found in catalytic properties of enzymes engaged in RFOs biosynthetic pathway and the lack of identification of enzymes responsible exclusively for the synthesis of galactosyl cyclitols (Peterbauer et al. 2003). The biosynthetic pathway of RFOs is determined by the activity of galactinol synthase (GolS), catalyzing the synthesis of galactinol from UDPgalactose and myo-inositol. Galactinol is the main galactosyl donor for the synthesis of raffinose, stachyose and verbascose (Peterbauer and Richter 2001). Raffinose synthase (RS), transferring the galactosyl moiety from galactinol to sucrose (producing raffinose), and stachyose synthase (STS), transferring the galactosyl moiety from galactinol to raffinose and stachyose (producing stachyose and verbascose, respectively), indicate multifunctional properties. They are able to transfer galactose to Dpinitol/D-ononitol and their galactosides (Peterbauer et al. 2002a, b). Moreover, STS from pea indicates an ability to catalyze the synthesis of verbascose from two molecules of stachyose (Peterbauer et al. 2003). 
The indirect confirmation of the synthesis of both RFOs and galactosyl pinitols by the same set of enzymes was found in developing Vicia villosa seeds (Lahuta 2006). The profiles of enzyme activity and the accumulation of RFOs and galactosyl pinitols were very consistent. Additionally, in seeds of Vicia species naturally accumulating only myo-inositol and RFOs, and not D-pinitol/galactosyl pinitols, the activity directed towards the synthesis of ciceritol and trigalactosyl pinitol A was found (Lahuta et al. 2010b). The accumulation of higher amounts of galactosyl pinitols in seeds may depend on D-pinitol (1D-3-Omethyl-chiro-inositol) at sufficiently high concentrations (Lahuta et al. 2005a, b, c, 2010a). This cyclitol is synthesized from myo-inositol by myo-inositol methyl transferase (IMT), catalyzing the synthesis of Dononitol (1D-4-O-methyl-myo-inositol), which is later epimerized (presumably in a two-step reaction) to Dpinitol (Peterbauer and Richter 2001). The synthesis of D-ononitol/D-pinitol was found in vegetative tissues, but not in seeds (Obendorf and Górecki 2012). Thus, the accumulation of galactosyl pinitols/ononitols in seeds seems to depend on the transport of cyclitols from vegetative tissues into developing seeds. In fact, exogenously applied D-pinitol (via stem-leaf-pod explants feeding with solution containing cyclitols) affects the biosynthesis of RFOs, leading to the accumulation of galactosyl pinitols and decline in the level of RFOs (Gomes et al. 2004; Lahuta et al. 2005b, c, 2010a). The negative correlation between the accumulation of RFOs and galactosyl pinitols in seeds of Vicia species (Lahuta et al. 2010b) and lentil seeds (Frias et al. 1999) justifies the suggestion that the diminishing of RFOs content by their replacement with galactosyl cyclitols is achievable by breeding. However, for this purpose it will be necessary to discover genotypes with the most favorable composition of galactosides in seeds. Moreover, in Vicia species containing only RFOs, the discovery of genotypes with reduced levels of RFOs should be also helpful in breeding programs.

In the present study, the composition and content of soluble carbohydrates was analyzed in seeds of 166 accessions of 10 Vicia species. Although we focused on the RFOs/GalCs levels in seeds of three Vicia species: V. sativa, V. narbonensis and V. ervilia, the composition of soluble carbohydrates in seven wild Vicia species has not been previously demonstrated and can provide additional data to assist in the establishment of the taxonomy of species of the genus Vicia.

\section{Materials and methods}

\section{Material}

Seeds of 10 Vicia species were derived from Gene Bank in Gatersleben (Germany), whereas 17 cultivars and breeding lines of Vicia sativa $\mathrm{L}$. were derived from a collection of the Institute of Plant Genetics in Poznań (Poland). The investigated Vicia species belong to subgenus Vicia, Cracca and Ervum. Seven species from the sections: Vicia (V. angustifolia L., V. cordata Wulfen ex Hoppe, V. macrocarpa (Moris) Bertol and $V$. sativa L.), Narbonensis (V. narbonensis L. and $V$. johannis Tamamsch.) and Hypechusa ( $V$. pannonica Crantz) in the subgenus Vicia, two species (V. articulata Hornem. and V. monantha Retz.) from the section Cracca in the subgenus Cracca, and one (V. ervilia (L.) Willd.) from the section Ervilia in the subgenus Ervum were used. The Latin and English names of the investigated species, details of seeds' origin, codes and number of accessions are given in Online Resources (Table 1). The highest number of accessions was analyzed among species: $V$. sativa (66), V. ervilia (13) and V. narbonensis (11). Investigated accessions grown in Experimental Field Polish Academy of Sciences located in Cerekwica $\left(51^{\circ} 55^{\prime} \mathrm{N}\right.$, $\left.17^{\circ} 21^{\prime} \mathrm{E}\right)$ in 2015 year, in 1 replication. The seeds were sown in rows ( $3 \mathrm{~m}$ long) and spacing of $50 \mathrm{~cm}$ between rows. Dry pods with seeds, collected from several plants, were combined and used for analyses of soluble carbohydrates.

Analyses of soluble carbohydrates

The composition and content of soluble carbohydrates were analyzed by the high resolution gas chromatography method, as described earlier (Lahuta 2006). Seeds $(1 \mathrm{~g})$ were pulverized in a mixer mill MM200 (Retsch, Germany) for $2 \mathrm{~min}$ at the frequency of $22 \mathrm{~Hz}$. Carbohydrates were extracted from pulverized material (40-45 mg each, in 3 replications) with $900 \mu \mathrm{L}$ of $50 \%$ aqueous ethanol solution containing xylitol $(100 \mu \mathrm{g})$ as an internal standard. After heating at $90{ }^{\circ} \mathrm{C}$ for $30 \mathrm{~min}$ (with continuous shaking at $300 \mathrm{rpm})$, samples were centrifuged $(21,000 \times g$ for 


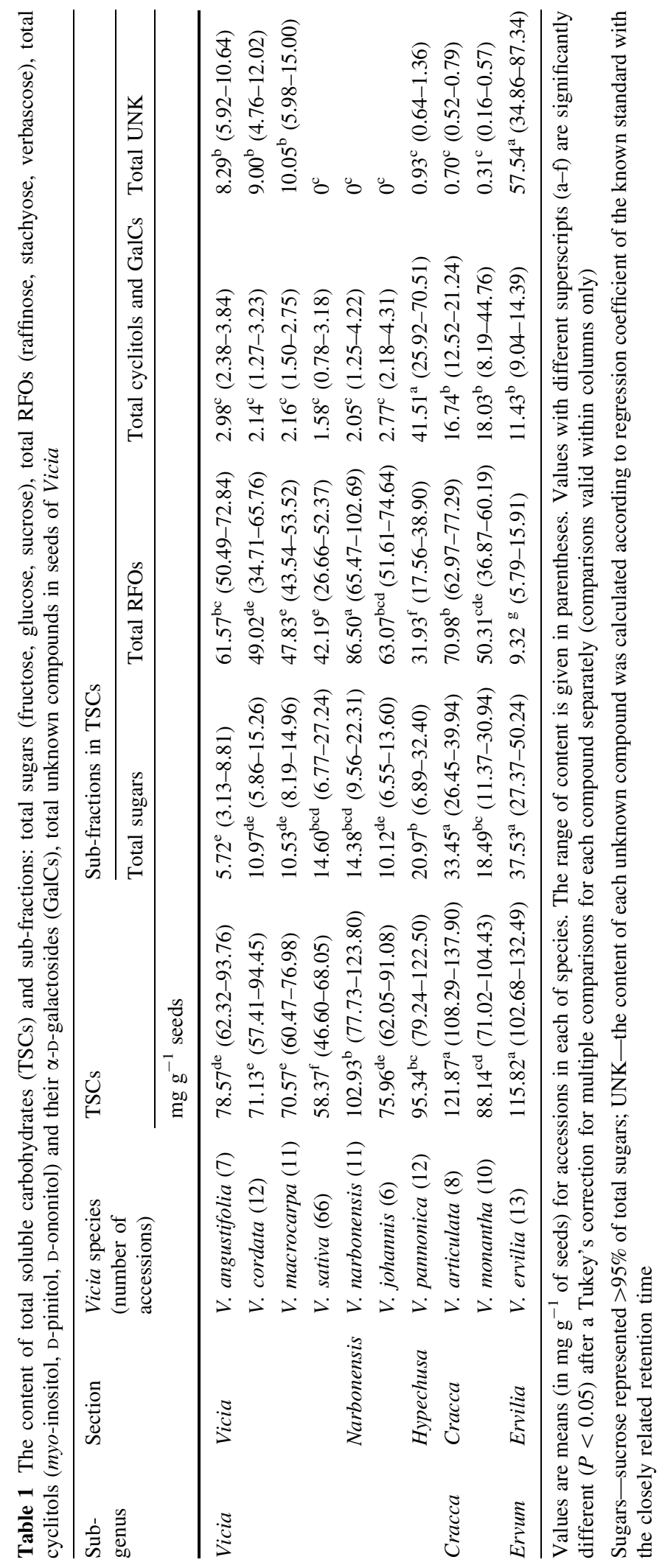



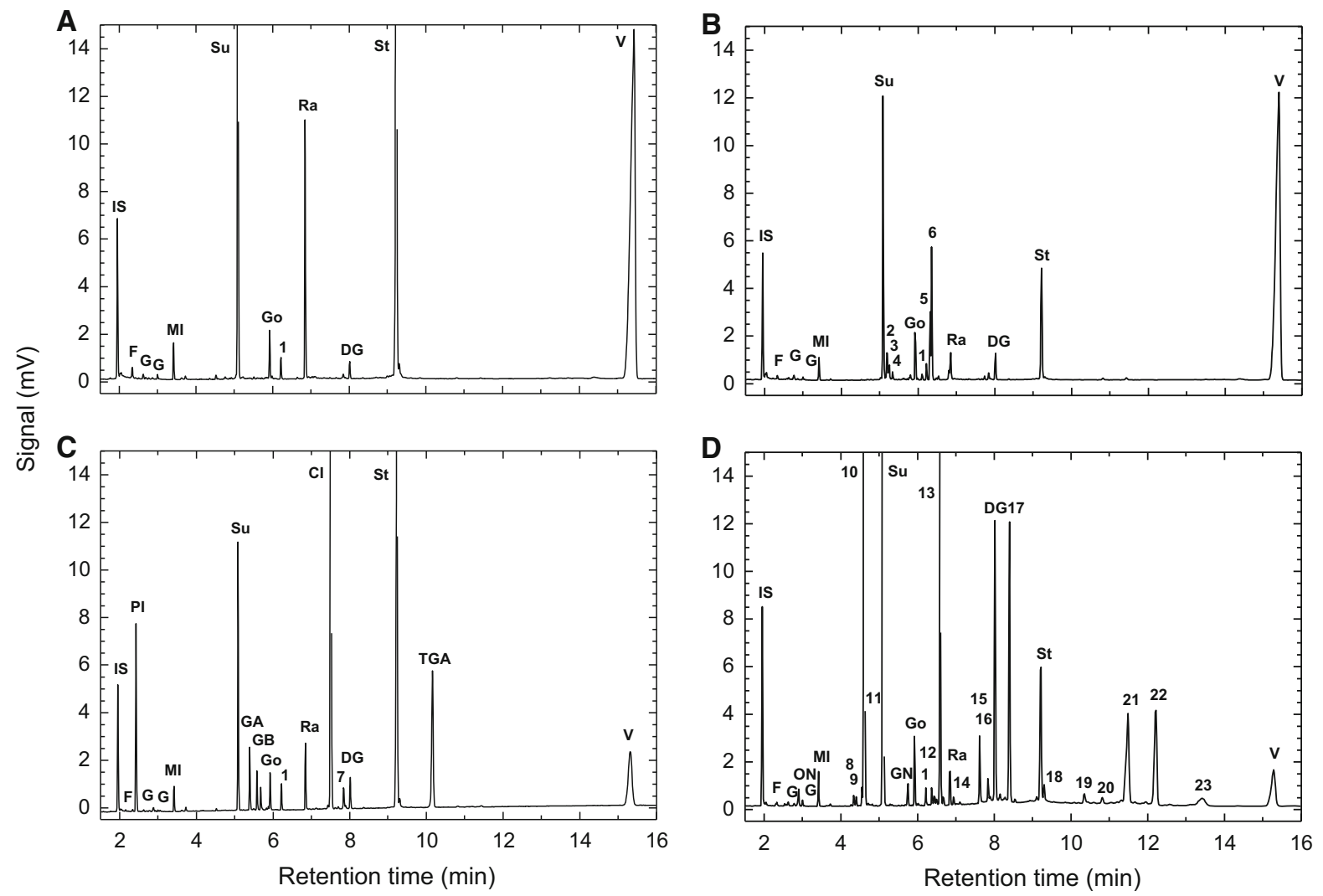

Fig. 1 Gas chromatograms of soluble carbohydrates extracted from seeds of four groups of Vicia species: A V. johannis and $V$. narbonensis, B V. angustifolia, V. cordata, V. macrocarpa and $V$. sativa, C V. articulata, $V$. monantha and $V$. pannonica, $\mathbf{D}$. ervilia. This figure demonstrates the separation of soluble carbohydrates from seeds of species showing differences in sugars, RFO, cyclitols, galactosyl cyclitols, and unknown compounds by gas chromatography. Identification of

$30 \mathrm{~min}$ at $4{ }^{\circ} \mathrm{C}$ ) and $400 \mu \mathrm{L}$ of homogenate was deionized with the mixture $(300 \mu \mathrm{L})$ of Dowex ion exchange resins for $45 \mathrm{~min}$ (with shaking at $1250 \mathrm{rpm}$ ). After centrifugation, a portion of the clear extract $(200 \mu \mathrm{L})$ was concentrated (in $2 \mathrm{ml}$ gas chromatography vials containing glass inserts) in a rotary evaporator until dry. Dry residues were derivatized with a mixture of TMSI (trimethylsilyl-imidazole) and pyridine $(1: 1, \mathrm{v} / \mathrm{v})$ at $80^{\circ} \mathrm{C}$ for $45 \mathrm{~min}$. TMS-derivatives of carbohydrates were separated in a ZB-1 capillary column (15 m length, $0.25 \mathrm{~mm}$ diameter, $0.1 \mu \mathrm{m}$ thickness, Phenomenex, USA) in a GC 2010 gas chromatograph (Shimadzu, Japan). The temperature of the injector and detector (flame ionization detector) was 325 and $350{ }^{\circ} \mathrm{C}$, respectively. The column was heated from 150 to $350{ }^{\circ} \mathrm{C}$ at

compounds: $I S$ xylitol (internal standard), $F$ fructose, $G$ glucose, MI myo-inositol, $\mathrm{Su}$ sucrose, Go galactinol (galactosyl myoinositol), 1 di-galactosyl glycerol (presumably), $R a$ raffinose, $D G$ di-galactosyl myo-inositol, $S t$ stachyose, $V$ verbascose, $P I$ Dpinitol, $G A$ galactosyl pinitol A, $G B$ glactosyl pinitol B, $C I$ ciceritol (di-galactosyl pinitol A), TGA tri-galactosyl pinitol A, $O N$ D-ononitol, $G N$ galactosyl ononitol, 2-23 unknown compounds

different rates of temperature increase. Helium was used as a carrier gas. Chromatograms were analyzed with an integrator in the CHROMA 3.2 application (Pol-Lab, Poland). Each carbohydrate was quantified by using authentic standards (sugars, cyclitols, oligosaccharides and galactinol) purchased from Sigma-Aldrich (USA). Standards of galactosyl pinitols: galactosyl pinitol A (GPA), galactosyl pinitol B (GPB), di- and tri-galactosyl pinitol A (ciceritol and TGPA, respectively), commercially unavailable, were extracted and purified from seeds of Vicia villosa Roth (Szczeciński et al. 2000).

Di-galactosyl myo-inositol (DGMI) and galactosyl ononitol, isolated from seeds of Vicia cracca and Vigna angularis by the method described previously (Szczeciński et al. 2000) were tentatively identified 
after their hydrolysis to galactose and myo-inositol/Dononitol $\left(2 \mathrm{~N}\right.$ trifluoroacetic acid, $\left.80{ }^{\circ} \mathrm{C}, 2 \mathrm{~h}\right)$. The content of the analyzed carbohydrates was calculated by the internal standard method. The contents of unidentified compounds (peaks no 1-23, Fig. 1) were calculated according to the regression coefficients for the known carbohydrate standards with the closest retention time. Thus, these calculations are only approximate.

\section{Statistical analysis}

The results were presented (in $\mathrm{mg} \mathrm{g}^{-1}$ of seeds) as means from three replications. The significance of differences in the concentrations of various carbohydrates was determined by one-way ANOVA with the Tukey's test. Data were also analyzed using multivariate methods. The canonical variable analysis was applied in order to present multitrait assessment of similarity of the tested species in a lower number of dimensions with the least possible loss of information (Rencher 1992). This makes it possible to illustrate variation in species in terms of all observed traits in a graphic form. Mahalanobis' distance was suggested as a measure of "polytrait" species similarity (SeidlerŁożykowska and Bocianowski 2012), whose significance was verified by means of critical value $D_{\alpha}$ called "the least significant distance" (Mahalanobis 1936). Mahalanobis' distances were calculated for species. All the analyses were conducted using the GenStat v. 17 statistical software package.

\section{Results and discussion}

The carbohydrate composition in Vicia seeds

The composition of soluble carbohydrates in seeds of the analyzed Vicia species has not been reported earlier, except for a few genotypes of $V$. angustifolia (Lahuta et al. 2005a), V. sativa and V. narbonensis (Yasui et al. 1987; Lahuta et al. 2005a). In the present study, the gas chromatographic analyses revealed distinct composition of soluble carbohydrates in seeds among the investigated Vicia species (Fig. 1). Common carbohydrates (fructose, glucose, sucrose, raffinose, stachyose, verbascose, myo-inositol, galactinol and DGMI) and species-specific cyclitols: D-pinitol, Dononitol and their $\alpha$-D-galactosides, were determined in the seeds (Fig. 1). Moreover, several compounds (containing sugar moieties) found in GC-chromatograms were not identified. Their identity with other galactosyl cyclitols (GalCs) occurring in some legumes (galactosides of D-chiro-inositol or D-ononitol) can be excluded because of: (1) differences between retention times of the unidentified compounds and retention times of galactosyl cyclitols standards and (2) absence of myo-inositol isomers/ methyl derivatives (excluding D-pinitol/D-ononitol).

According to the differences in the composition of soluble carbohydrates in seeds, Vicia species can be classified into four groups (A-D, Fig. 1). In the first group (A), fructose, glucose, myo-inositol, sucrose, RFOs, galactinol and DGMI were present (Fig. 1A). Beside two compounds, di-galactosyl glycerol (peak no. 1 on Fig. 1A) and presumably pyrimidine glycoside, vicine (2,6-diamino-4-hydroxy-5-pyrimidinyl $\beta$-D-glucopyranoside, peak no. 2 on Fig. 1B), common for all Vicia species (Yasui and Ohashi 1990), no other carbohydrates were found. Such composition of carbohydrates characterized seeds of $V$. johannis and V. narbonensis (section Narbonensis). Among RFOs, verbascose was the dominant oligosaccharide.

In the second group: $V$. angustifolia, $V$. cordata, $V$. macrocarpa and V. sativa (section Vicia), the share of verbascose in RFOs was the highest (84-88\%) among all the investigated Vicia species, and seeds contained also considerable amounts of a few unidentified compounds (peaks no. 2-6, Fig. 1B). The higher concentration of verbascose in seeds of $V$. angustifolia than in seeds of different Vicia species (in the subgenera Vicia and Vicilla) was described earlier by Lahuta et al. (2010b). Some accessions of $V$. sativa differed in the content of an unknown compound (peak no 6, Fig. 1B), presumably vicianine ( $\alpha$-cyanobenzyl $6-O-\alpha$-L-arabinopyranosyl- $\beta$-D-glucopyranoside), occurring in this Vicia species (Yasui and Ohashi 1990).

Seeds of the third group, including $V$. articulata, $V$. monantha (section Cracca) and V. pannonica (section Hypechusa), beside having RFOs contained D-pinitol and its galactosides: GPA, GPB, ciceritol and TGPA, (Fig. 1C). In some species from the section Cracca ( $V$. cracca, V. hirsuta, V. villosa) and Hypechusa ( $V$. tetrasperma) the relative proportions of mono- di- and tri-galactosyl pinitols are different and species-specific (Yasui et al. 1987; Lahuta et al. 2005a, b, c, 2010b; Lahuta 2006). Our results confirm the accumulation of D-pinitol and galactosyl pinitols in seeds as a common 
Table 2 The content of sucrose, raffinose, stachyose and verbascose in seeds of Vicia

\begin{tabular}{|c|c|c|c|c|c|c|}
\hline \multirow{2}{*}{$\begin{array}{l}\text { Sub- } \\
\text { genus }\end{array}$} & \multirow[t]{2}{*}{ Section } & \multirow[t]{2}{*}{ Vicia species } & Sucrose & Raffinose & Stachyose & Verbascose \\
\hline & & & \multicolumn{4}{|l|}{$\mathrm{mg} \mathrm{g}^{-1}$ seeds } \\
\hline \multirow[t]{7}{*}{ Vicia } & \multirow[t]{4}{*}{ Vicia } & V. angustifolia & $5.47^{\mathrm{f}}(2.96-8.49)$ & $0.71^{\mathrm{d}}(0.50-0.86)$ & $6.47^{\mathrm{ef}}(4.72-8.33)$ & $54.39^{\mathrm{a}}(45.20-63.65)$ \\
\hline & & V. cordata & $10.65^{\mathrm{d}}(5.62-14.74)$ & $0.76^{\mathrm{d}}(0.40-1.46)$ & $6.84^{\mathrm{e}}(4.41-10.06)$ & $41.42^{\mathrm{c}}(29.74-55.41)$ \\
\hline & & V. macrocarpa & $10.41^{\mathrm{d}}(8.09-14.86)$ & $1.04^{\mathrm{d}}(0.71-1.29)$ & $6.60^{\mathrm{e}}(5.69-7.45)$ & $40.19^{\mathrm{c}}(35.04-46.09)$ \\
\hline & & V. sativa & $14.26^{\mathrm{e}}(6.48-26.72)$ & $2.29^{\mathrm{c}}(0.81-4.36)$ & $8.61^{\mathrm{e}}(5.40-12.07)$ & $31.29^{\mathrm{d}}(14.27-42.86)$ \\
\hline & \multirow[t]{2}{*}{ Narbonensis } & V. narbonensis & $13.96^{\mathrm{de}}(9.04-21.92)$ & $6.82^{\mathrm{a}}(4.70-10.02)$ & $31.32^{\mathrm{b}}(21.37-48.01)$ & $48.36^{\mathrm{b}}(35.67-66.95)$ \\
\hline & & V. johannis & $9.92^{\text {cdf }}(6.36-13.40)$ & $1.23^{\mathrm{d}}(0.88-1.72)$ & $9.51^{\mathrm{e}}(6.68-11.53)$ & $53.34^{\mathrm{ab}}(43.94-61.39)$ \\
\hline & Hypechusa & $V \cdot$ pannonica & $20.71^{\mathrm{b}}(6.77-31.98)$ & $3.83^{\mathrm{b}}(1.82-6.14)$ & $19.62^{\mathrm{d}}(9.26-26.07)$ & $8.48^{\mathrm{f}}(6.40-16.71)$ \\
\hline \multirow[t]{2}{*}{ Cracca } & \multirow[t]{2}{*}{ Cracca } & V. articulata & $33.17^{\mathrm{a}}(26.20-39.74)$ & $7.38^{\mathrm{a}}(5.52-10.52)$ & $47.14^{\mathrm{a}}(38.07-53.58)$ & $16.46^{\mathrm{e}}(10.41-20.42)$ \\
\hline & & V. monantha & $19.01^{\mathrm{bc}}(10.75-30.28)$ & $7.42^{\mathrm{a}}(2.96-10.81)$ & $26.10^{\mathrm{c}}(19.03-39.52)$ & $16.79^{\mathrm{e}}(2.99-28.82)$ \\
\hline Ervum & Ervilia & V. ervilia & $37.24^{\mathrm{a}}(27.1-49.89)$ & $0.78^{\mathrm{d}}(0.56-1.05)$ & $4.15^{\mathrm{f}}(2.89-6.24)$ & $4.40^{\mathrm{f}}(2.22-8.77)$ \\
\hline
\end{tabular}

Values are means for accessions in each of species. In parentheses the range of concentrations was showed. Values with different superscripts $(\mathrm{a}-\mathrm{f})$ are significantly different $(P<0.05)$ after a Tukey's correction for multiple comparisons for each compound separately (comparisons valid within columns only)

feature of species belonging to both sections: Cracca and Hypechusa.

In seeds of the last group (one species V. ervilia), Dpinitol was absent, whereas D-ononitol—a precursor in the biosynthetic pathway of D-pinitol (Peterbauer and Richter 2001) and galactosyl ononitol were detected (Fig. 1D). Both compounds were identified earlier in seeds of $V$. tetrasperma, belonging to the section Ervum and $V$. dumetorum from the section Vicilla (Yasui et al. 1987). However, seeds of both $V$. tetrasperma and $V$ dumetorum contained also D-pinitol and its galactosides (Yasui et al. 1987; Lahuta et al. 2005b), which were absent in V. ervilia (our study). Although Muzquiz et al. (2015) reported the presence of galactopinitol and ciceritol in seeds of two cultivars of V. ervilia (Villanueva and Taranto), our results (13 accessions) contradict the occurrence of D-pinitol and galactosyl pinitols in V. ervilia (Fig. 1D). Moreover, the retention times of two peaks, present in GC chromatograms of extracts from $V$. ervilia seeds (peaks no. 10 and 11, between myo-inositol and sucrose, Fig. 1D), were identical with retention times of two compounds occurring in seeds of V. hirsuta and V. sylvatica only (Yasui et al. 1987; Lahuta et al. 2010b). Other unique features of the composition of carbohydrates in seeds of $V$. ervilia were: (1) the lowest amount of RFOs, as compared to other Vicia species; (2) the highest content of DGMI and (3) the considerable amounts of several unidentified compounds (Fig. 1D, peaks no. 8-23), with retention times differing from those unknown compounds found in seeds of the second Vicia group (Fig. 1B).

The content of soluble carbohydrate in seeds

The content of soluble carbohydrates in seeds (means and a range for species) is presented in Tables 1,2, 3 . Species are listed in the order of their current taxonomic classification (Leht 2005; Jaaska 2008; Schaefer et al. 2012; Smýkal et al. 2015). In view of a very low content of fructose and glucose $\left(<1 \mathrm{mg} \mathrm{g}^{-1}\right.$ seeds), these data were omitted.

The significantly $(P<0.05)$ highest content of total soluble carbohydrates (TSCs) was found in seeds of $V$. articulata (section Cracca in subgenus Cracca) and $V$. ervilia (section Ervilia in subgenus Ervum): 121.87 and $115.82 \mathrm{mg} \mathrm{g}^{-1}$, respectively (Table 1 ). The reason was the high content of sucrose and RFOs, or sucrose and unknown compounds, in $V$. articulata and $V$. ervilia, respectively (Tables 1,2 ). In seeds of all accessions of $V$. articulata and $V$. ervilia, the level of TSCs was above $100 \mathrm{mg} \mathrm{g}^{-1}$. A two-fold lower content of TSCs in seeds of V. sativa (subgenus Vicia, section Vicia) $-58.37 \mathrm{mg} \mathrm{g}^{-1}$ was found (Table 1). The range of TSCs in this species was also low: 46.60-68.05 $\mathrm{mg} \mathrm{g}^{-1}$.

The main sub-fraction of soluble carbohydrates consisted of raffinose oligosaccharides (RFOs), making up from $57 \%$ (V. monantha) to $84 \%$ of TSCs ( $V$. narbonensis $)$. The significantly $(P<0.05)$ highest 


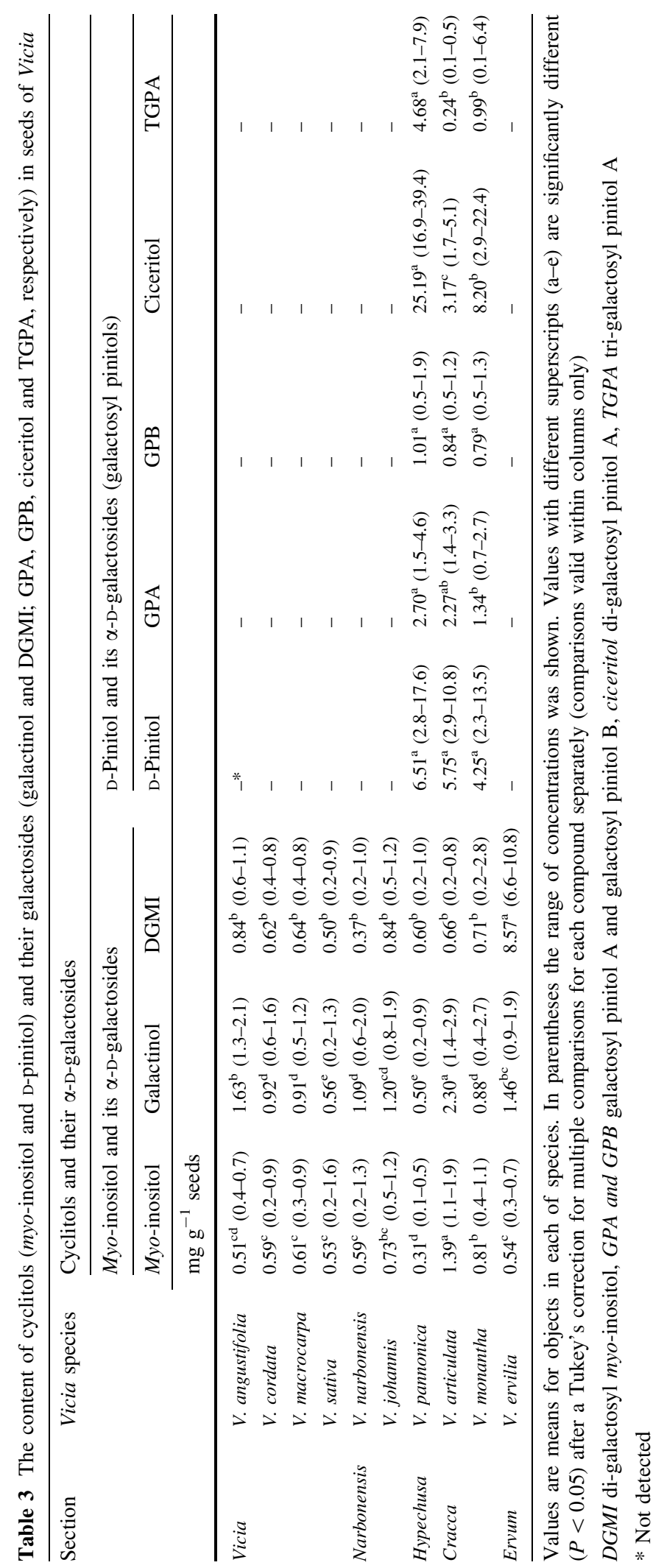


content of RFOs (mean $86.50 \mathrm{mg} \mathrm{g}^{-1}$ ) was found in seeds of $V$. narbonensis (Table 1). In seeds of other economically important Vicia species-V. sativa (common vetch) and V. ervilia (bitter vetch), the content of RFOs was two-fold and ca 10-fold lower (respectively) than in $V$. narbonensis (Table 1). The high level of RFOs in $V$. narbonensis, found in our study (Tables 1,2), is consistent with results obtained by Rolletschek et al. (2002) and Martín-Pedrosa et al. (2016). In a wild type of $V$. narbonensis, the level of RFOs was $70.2 \mathrm{mg} \mathrm{g}^{-1}$ dry mass, whereas in lines with a disrupted starch biosynthesis pathway, the level of RFOs increased up to $94 \mathrm{mg} \mathrm{g}^{-1}$ dry mass (Rolletschek et al. 2002). In our study, some accessions of $V$. narbonensis, suitable for a breeding program dedicated to the lowering of the level of RFOs in seeds, were identified. The lowest content of RFOs (65-67 $\mathrm{mg} \mathrm{g}^{-1}$ ) was found in accessions: VNAR154 (from Italy) and VNAR139 (Spain). In all the accessions of narbon vetch, verbascose was the predominant oligosaccharide in RFOs.

In common vetch, a few genotypes (out of 66 analyzed) with a decreased content of RFOs (26.6-35.9 $\mathrm{mg} \mathrm{g}^{-1}$ ) in seeds were found. They are two Polish cultivars, Ina and Kamiko, the Czech cultivar Kraj Ołomun and accessions from Albania (VIC121), Latvia (VIC541), Sweden (VIC273), Yugoslavia (VIC542), Turkey (VIC101), Mongolia (VIC664) and Ukraine (VIC749). Verbascose was the predominant oligosaccharide (Table 2). In our previous study, a low content of RFOs $\left(36.7 \mathrm{mg} \mathrm{g}^{-1}\right.$ dry mass) was found in seeds of $V$. sativa $\mathrm{cv}$. Kamiko and Kwarta (Lahuta et al. 2010a, b). The mean content of RFOs in seeds of accessions of $V$. sativa is as high (42.19 $\mathrm{mg} \mathrm{g}^{-1}$ ) as in seeds of Vicia faba (Yasui et al. 1987; Guillon and Champ 2002) and V. faba var. minor (Zalewski and Lahuta 1998).

Seeds of bitter vetch contained the lowest amount of RFOs (mean for 13 accessions $9.32 \mathrm{mg} \mathrm{g}^{-1}$ ) among 10 investigated Vicia species (Table 1). Similarly low levels of RFOs were estimated recently by MartínPedrosa et al. (2016) in seeds of two bitter vetch cultivars. Such a low level of RFOs is unique among legumes (Kadlec et al. 2001). Moreover, in 3 of the 13 bitter vetch accessions analyzed: ERV93 (France), ERV524 (Bulgary) and ERV94 (Afghanistan), the content of RFOs was below $7 \mathrm{mg} \mathrm{g}^{-1}$, whereas in 4it was above $10 \mathrm{mg} \mathrm{g}^{-1}$ (data not presented). Verbascose or stachyose were main oligosaccharides in
RFOs. The low amount of RFOs coincided with the highest content of sucrose (Table 2) and di-galactosyl myo-inositol (DGMI, Table 3). Such composition indicates that synthesis and accumulation of DGMI in $V$. ervilia seeds occurs concurrently with the synthesis of RFOs. The transfer of the galactosyl moiety from galactinol to sucrose (producing raffinose) and then to raffinose and stachyose seems to be impaired by the transfer to galactinol, producing DGMI. Thus far, no data have been made available that would identify the enzyme controlling this reaction. It can be supposed that multifunctional STS (Peterbauer and Richter 2001; Peterbauer et al. 2002b) and RS (Peterbauer et al. 2002a) can catalyze the transfer of the galactosyl moiety from one molecule of galactinol to another. D-Pinitol was absent in $V$. ervilia, but its seeds contained D-ononitol $\left(0.42 \mathrm{mg} \mathrm{g}^{-1}\right)$, which can be used by STS as a substrate in the synthesis of galactosyl ononitol (Peterbauer and Richter 1998). In fact, galactosyl ononitol was detected in seeds of $V$. ervilia (0.43 $\mathrm{mg} \mathrm{g}^{-1}$, data not presented). The question remains whether some of secondary metabolites, occurring in V. ervilla at high concentrations $(49 \%$ of TSCs, Fig. 1d; Table 1), can regulate the activity of enzymes engaged in the biosynthesis of RFOs. Moreover, the presence of D-ononitol (precursor in biosynthesis of D-pinitol, Peterbauer and Richter 2001) and galactosyl ononitol in seeds, which is a trait of only few legumes (Yasui and Ohashi 1990; Peterbauer and Richter 1998), and the absence of D-pinitol implicate that the epimerization of D-ononitol to D-pinitol does not operate in V. ervilia. Thus, the role of V. ervilia as a presumed ancestor of other Vicia species, accumulating D-pinitol and galactosyl pinitols beside RFOs, awaits clarification. The presence of galactopinitol and ciceritol in seeds of cultivated bitter vetch, reported by Martín-Pedrosa et al. (2016), is not possible without the presence of D-pinitol, and can be a result of incorrect identification of some peaks in GC-chromatograms (Fig. 1d), due to the lack of appropriate standards.

Among the investigated Vicia species, D-pinitol and galactosyl pinitols were accumulated in seeds of $V$. pannonica, V. articulata and V. monantha (Table 3). Galactosyl ononitol was absent, whereas D-ononitol was below the detection limit or only in trace amounts (not presented data). In seeds accumulating D-pinitol, the concentration of its intermediate, i.e. D-ononitol, is 
generally very low (Yasui et al. 1987; Lahuta et al. 2005b; Obendorf et al. 2012). Seeds of V pannonica contained a significantly higher $(P<0.05)$ amount of galactosyl cyclitols $\left(41.51 \mathrm{mg} \mathrm{g}^{-1}\right)$ than seeds of $V$. articulata and $V$. monantha (6.49 and $11.32 \mathrm{mg} \mathrm{g}^{-1}$, respectively, Table 1). Ciceritol was the main galactosyl pinitol (Table 3). Seeds of $V$. pannonica also contained the highest amount of TGPA (4.68 $\mathrm{mg} \mathrm{g}^{-1}$ ). In seeds containing D-pinitol, the content of its galactosides significantly increased the participation of total GalCs in TSCs (up to $36.2 \%$ in $V$. pannonica). In seeds of $V$. pannonica, the high level of galactosyl pinitols ( $33.58 \mathrm{mg} \mathrm{g}^{-1}$, Table 3) coincided with the low level $\left(31.93 \mathrm{mg} \mathrm{g}^{-1}\right)$ of RFOs, as compared to the other species of the subgenera Vicia and Cracca (Table 1). A negative relationship between the level of RFOs and GalCs was found earlier in seeds of $V$. tenuifolia and $V$. cracca (Lahuta et al. 2010a). The content of galactosyl pinitols in seeds of $V$. pannonica (Table 3) was lower $\left(33.58 \mathrm{mg} \mathrm{g}^{-1}\right.$ ) than in $V$. cracca and $V$. tenuifolia, 44.7 and $70.1 \mathrm{mg} \mathrm{g}^{-1}$, respectively (Lahuta et al. 2010a), and similar to V. villosa (Lahuta et al. 2010b). However, tetra-galactosyl pinitol A, present in seeds of $V$. tetrasperma, $V$. villosa, $V$. cracca and $V$. tenuifolia (Lahuta et al. 2010a, b), was not detected in $V$. pannonica.

Statistical analyses of our results confirmed the taxonomic classification of the investigated Vicia species. The Vicia species can be separated according to the results of a canonical variable analysis of the content of all soluble carbohydrates (including unidentified compounds) in seeds (Fig. 2). The first two canonical variables accounted for $88.69 \%$ of the total multivariate variability between Vicia species (Fig. 2). The greatest variability in terms of all the analyzed traits expressed jointly with the greatest Mahalanobis distance was recorded for the V. ervilla and $V$. articulata (Mahalanobis distance equal to 22.605) as well as between V. ervilla and V. angustifolia (20.979). In turn, the strongest phenotypic similarity was observed for $V$. sativa and $V$. cordata (2.391), V. narbonensis and V. johannis (2.526) as well as for $V$. sativa and $V$. macrocarpa (2.671) (Online resource, Table 1). The separation of $V$. ervilia from other Vicia species is a result of its lowest level of RFOs, highest content of DGMI, absence of D-pinitol (and its galactosides) and presence of unknown compounds at high concentrations
(Tables 1, 2, 3). Seeds of V. cordata, V. monanta and $V$. pannonica accumulate higher amounts of sucrose, stachyose (Table 2), D-pinitol and its galactosides (Table 3). The differences in the composition of carbohydrates in the remaining 6 Vicia species are smaller (Fig. 2).

The presence of D-pinitol/D-ononitol (and galactosyl cyclitols) or unknown compounds seems to be a trait that substantiates some preliminary confirmation of the taxonomic classification of Vicia species. However, the phylogenetic tree constructed according to myo-inositol, galactinol, DGMI, raffinose, stachyose and verbascose (cyclitol and $\alpha$-D-galactosides common for 10 Vicia species) indicated an evolution of two descendants-the subgenus Cracca and an unknown one, from which presumably the subgenera Ervum and Vicia evolved. The latter one differentiated into the sections Vicia and Narbonensis (Fig. 3).

The infrageneric variation of low molecular weight carbohydrate composition in Vicia (as well in all Fabaceae) can be an effect of both evolutionary trends and domestication, as suggested Yasui and Ohashi (1990). Although narbon and common vetch belong to legumes domesticated early (Schaefer et al. 2012; Smýkal et al. 2015), they did not develop enzymatic pathways leading to the synthesis of myo-inositol isomers/methyl derivatives. Such an important evolutionary trait developed in bitter vetch, another Vicia species domesticated early (Mikić et al. 2015). The primitive ancestors accumulated RFOs in seeds, whereas the ability to synthesize galactosides of myo-inositol methyl derivatives (D-ononitol, D-pinitol, D-bornesitol) developed later, as a result of the synthesis of different cyclitols in vegetative tissues, presumably due to the pressure of unfavorable environmental conditions. The accumulation of methyl derivatives of myo-inositol can be an element of mechanisms ensuring tolerance to abiotic stresses such as: salinity, drought and cold (Merchant and Richter, 2011). Developing embryos are unable to convert myo-inositol into methyl derivatives, or even to epimerize of D-ononitol to D-pinitol (Obendorf and Górecki 2012). Thus, the accumulation of such cyclitols and the biosynthesis of appropriate galactosyl cyclitols in seeds arise from the synthesis of cyclitols in vegetative tissues and their temporary transport from the mother plant to seeds. Consequently, cyclitols can redirect the accumulation of galactose from RFOs into the GalCs pathway only at 


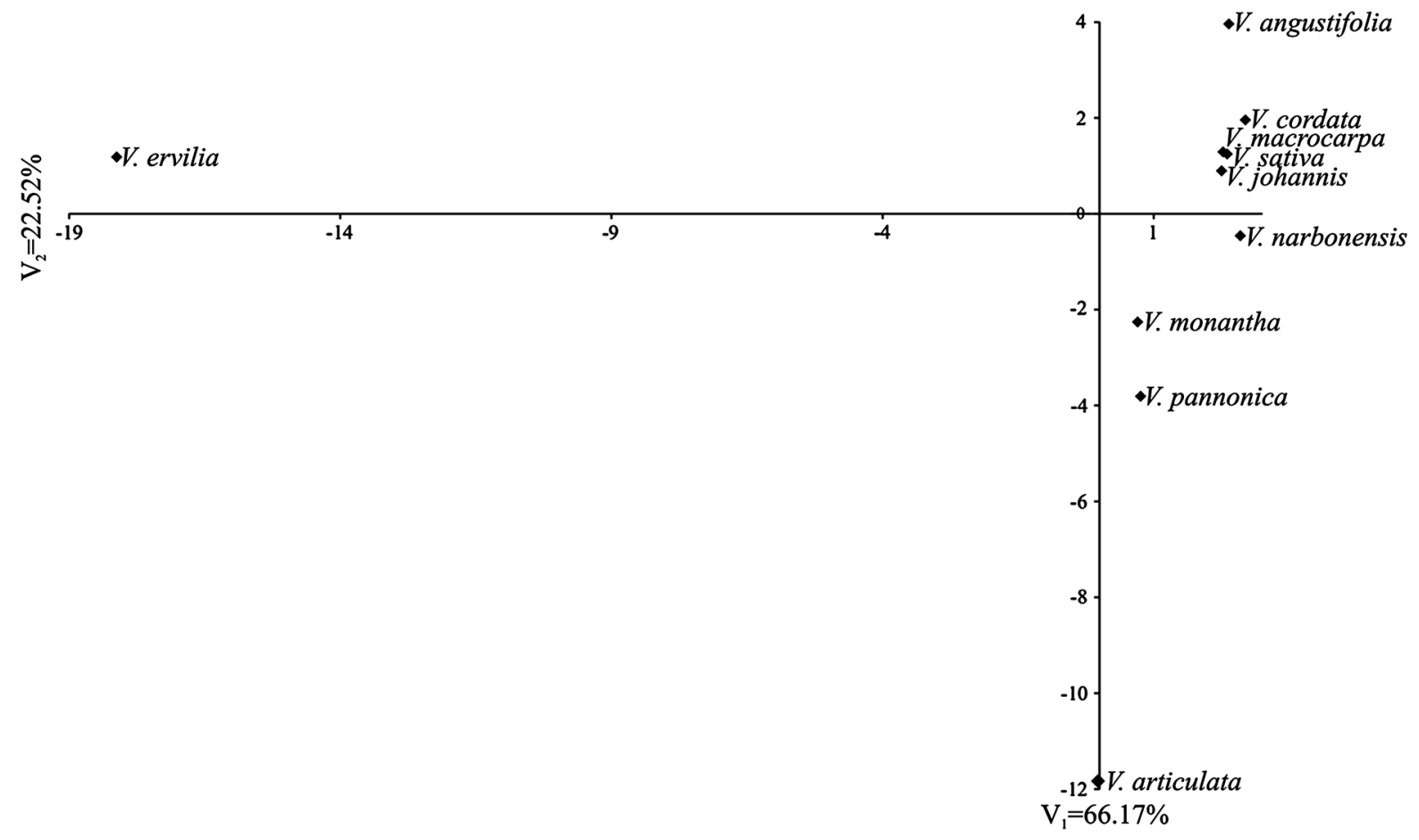

Fig. 2 Distribution of ten Vicia species studied in the space of two first canonical variables. Original data set: all identified carbohydrate and unidentified compounds

Fig. 3 Phylogenetic tree for 10 Vicia species based on the content of myo-inositol, galactinol, DGMI, raffinose, stachyose and verbascose in seeds

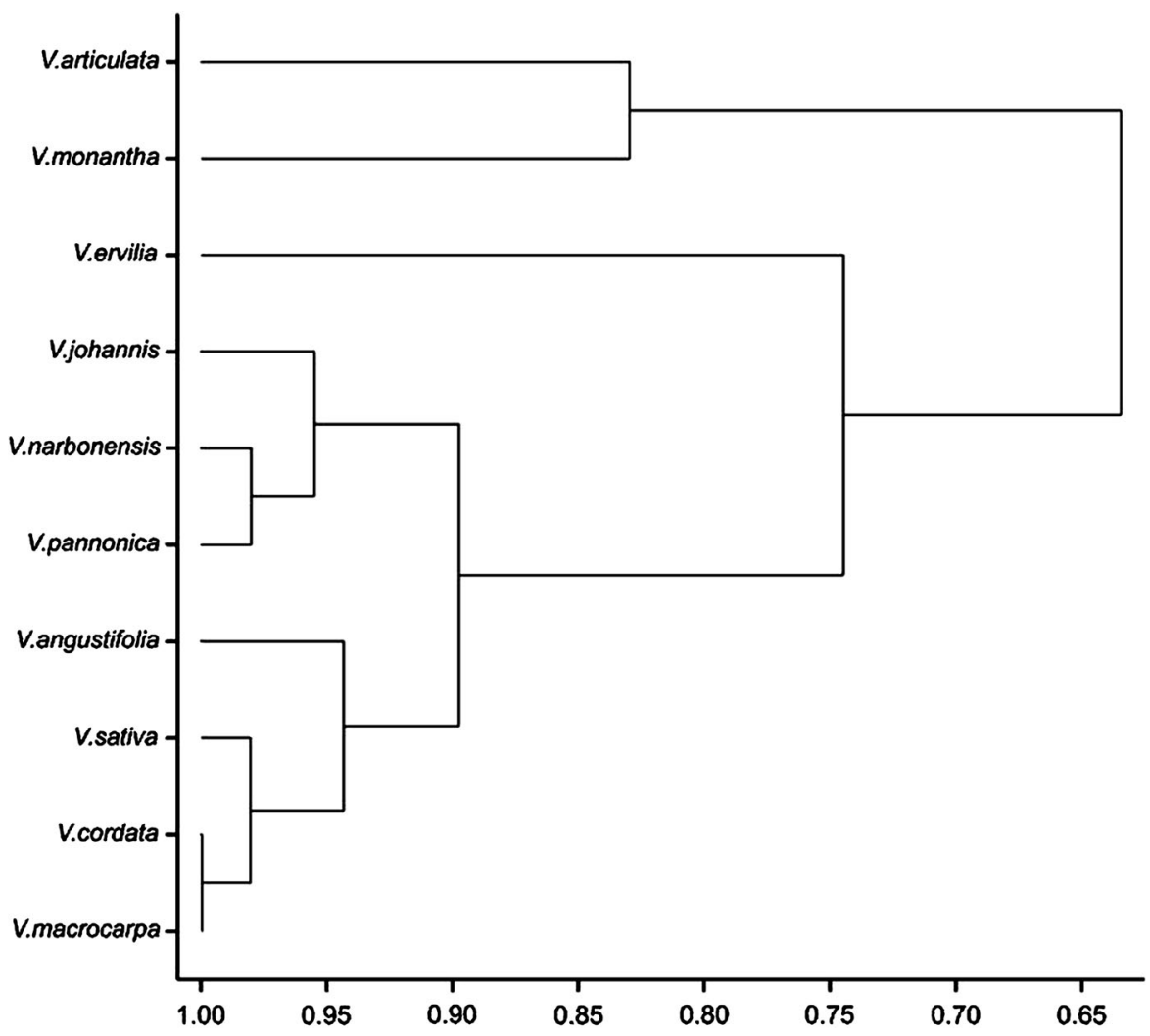


sufficiently high concentrations. Both galactinol synthase (GolS) and two enzymes synthesizing RFOs, i.e. RS and STS, indicate the ability to use specific cyclitols as galactosyl acceptors (Obendorf and Górecki 2012). The accumulation of GalCs in legumes instead of RFOs has not been documented yet. RFOs are mostly replaced by $\alpha$-D-galactosides of D-chiro-inositol, named fagopyritols only in seeds of buckwheat (Fagopyrum esculentum Moench, Polygonaceae) (Horbowicz et al. 1998). Beside galactinol (from UDP-galactose and myo-inositol), the two forms of Gols also demonstrate an ability to synthesize fagopyritol B1 ( $\alpha$-D-galactoside of Dchiro-inositol) or a mixture of fagopyritols (A1 and B1) from UDP-galactose and D-chiro-inositol (Ueda et al. 2005). Similar activity was found in Vicia seeds (Lahuta et al. 2005c). Some mutations in enzymes of the RFOs pathway found in soybean (Obendorf et al. 2008) lead to a decrease in RFOs and an increase in the amount of galactosyl cyclitols, which can enhance the imbibitional chilling tolerance of seeds (Obendorf et al. 2008). Karner et al. (2004) found a significant role of myo-inositol at elevated concentrations for the accumulation of higher amounts of RFOs in pea seeds. However, recessive mutations in main pea seed genes ( $R, A$ and $I$ ) seems to be more important for an increased content of RFOs (Gawłowska et al. 2017). Among 248 accessions of pea (derived form Polish Pisum Genebank) the highest content of RFOs were stated for accessions with wrinkled seeds ( $r$ and $r b$ genes), whereas the lowest content for seeds of the wild species P. fulvum Sibth. et Sm. It was found that the content of total RFOs was the most highly, frequently, and positively correlated with a stachyose and verbascose. In seeds of forty faba bean (Vicia faba L.) populations the concentration of RFOs ranged from 25 to $75 \mathrm{mg} \mathrm{g}^{-1}$ of dry mass, and verbascose was the predominant oligosaccharide (Landry et al. 2016). In chickpea and lentil occur D-pinitol and its galactosides (mainly ciceritol). In seeds of both species the concentration of ciceritol is as high as stachyose (the predominant RFO) (Xiaoli et al. 2008; Muzquiz et al. 2012). In lentil crosses, a large negative correlation was found between the level of verbascose and ciceritol in seed (Frias et al. 1999). However, they are not available data on diversity of D-pinitol and galactosyl pinitols among the more numerous accessions of genus Cicer and Lens. Thus, plants of the genus Vicia can be used as an excellent object for research on the evolution of the biosynthetic pathway of myo-inositol methyl derivatives.

\section{Conclusions}

The GC separation of TMS-derivatives of soluble carbohydrates can be a useful tool for preliminary identification of species belonging to different Vicia subgenera, which can be important during breeding programs of Vicia. Beside obvious carbohydrates: sucrose, myo-inositol, galactinol and raffinose family oligosaccharides (RFOs), seeds of some Vicia species contain species-specific cyclitols and their $\alpha$-D-galactosides. The presence of D-pinitol and its galactosides in seeds of V. pannnica, V. articulata and V. monantha has been demonstrated for the first time. Galactosyl ononitol was detected at a low concentration only in seeds of $V$. ervilia. Seeds of $V$. ervilia contained the lowest amount of RFOs, but the highest quantity of digalactosyl myo-inositol among all the analyzed Vicia species. Moreover, considerable amounts of unknown compounds were found in V. ervilia. Among cultivated species of Vicia, seeds of narbon vetch accumulate the highest amount of RFOs $\left(86.5 \mathrm{mg} \mathrm{g}^{-1}\right.$ ), whereas the level of RFOs in common vetch is twofold lower. Some accessions/cultivars of common vetch and narbon vetch with lowered levels of RFOs were found. The differences in soluble carbohydrates in seeds support the current taxonomic classification of the analyzed Vicia species.

Acknowledgements This study was partially supported by the programme "Improvement of native plant protein feeds, their production, trade turnover and utilization in animal feed" of the Ministry of Agriculture and Rural Development of Poland.

\section{Compliance with ethical standards}

Conflict of interest The authors declare that there is no conflict of interest regarding the publication of this paper.

Open Access This article is distributed under the terms of the Creative Commons Attribution 4.0 International License (http:// creativecommons.org/licenses/by/4.0/), which permits unrestricted use, distribution, and reproduction in any medium, provided you give appropriate credit to the original author(s) and the source, provide a link to the Creative Commons license, and indicate if changes were made. 


\section{References}

Croze MJ, Soulage CO (2013) Potential role and therapeutic interests of myo-inositol in metabolic diseases. Biohcimie 95:1811-1827

Enneking D, Wink M (2000) Towards the elimination of antinutritional factors in grain legumes. In: Knight $\mathrm{R}$ (ed) Linking research and marketing opportunities for pulses in the 21 st century. Kluwer Academic Publishers, Dordrecht, pp 671-683

Frias J, Bakhash A, Jones DA, Arthur AE, Vidal-Valverde C, Rhodes MJC, Hedley CL (1999) Genetic analysis of the raffinose oligosaccharide pathway in lentil seeds. J Exp Bot 50:469-476

Gawłowska M, Święcicki W, Lahuta L, Kaczmarek Z (2017) Raffinose family oligosaccharides in seeds of Pisum wild taxa, type lines for seed genes, domesticated and advanced breeding materials. Genet Resour Crop Evol 64:569-578

Gomes CI, Obendorf RL, Horbowicz M (2004) myo-Inositol, Dchiro-inositol, and D-pinitol synthesis, transport, and galactoside formation in soybean explants. Crop Sci 45(2):1312-1319

Guillon F, Champ MMJ (2002) Carbohydrate fractions of legumes: uses in human nutrition and potential for health. Brit J Nutr 88(Suppl 3):S293-S306

Gulewicz P, Martinez-Villaluenga C, Kasprowicz-Potocka M, Frias J (2014) Non-nutritive compounds in Fabaceae family seeds and the improvement of their nutritional quality by traditional processing - a review. Pol J Food Nutr Sci 64(2):75-89

Horbowicz M, Brenac P, Obendorf RL (1998) Fagopyritol B1, $O$ - $\alpha$-D-galactopyranosyl-(1-2)-D-chiro-inositol, a galactosyl cyclitol in maturing buckwheat seeds associated with desiccation tolerance. Planta 205:1-11

Jaaska V (2008) Isozyme evidence on the specific distinctness and phylogenetic position of Vicia incisa (Fabaceae). Centr Eur J Biol 3(2):169-176

Kadlec P, Bjergegaard C, Gulewicz K, Horbowicz M, Jones A, Kintia P, Kratchanov C, Kratchanova M, Lewandowicz G, Soral-Śmietana M, Sorensen H, Urban J (2001) Carbohydrate chemistry. In: Hedley CL (ed) Carbohydrates in grain legumes. Improving nutritional quality and agronomic characteristics. CABI Publishing, Wallingford, pp 15-59

Karner U, Peterbauer T, Raboy V, Jones DA, Hedley CL, Richter A (2004) myo-Inositol and sucrose concentrations affect the accumulation of raffinose family oligosaccharides in seeds. J Exp Bot 55:1981-1987

Lahuta LB (2006) Biosynthesis of raffinose family oligosaccharides and galactosyl pinitols in developing and maturing seeds of winter vetch (Vicia villosa Roth.). Acta Soc Bot Pol 75(3):219-227

Lahuta LB, Górecki RJ, Gojło E, Horbowicz M (2005a) Differences in accumulation of soluble $\alpha$-galactosides during seed maturation of several Vicia species. Acta Physiol Plant 27(2):163-171

Lahuta LB, Górecki RJ, Horbowicz M (2005b) High concentrations of D-pinitol or D-chiro-inositol inhibit the biosynthesis of raffinose family oligosaccharides in maturing smooth tare (Vicia tetrasperma [L.] Schreb.) seeds. Acta Physiol Plant 27(4A):505-513
Lahuta LB, Horbowicz M, Gojło E, Goszczyńska J, Górecki RJ (2005c) Exogenously applied D-pinitol and D-chiro-inositol modifies the accumulation of $\alpha$-D-galactosides in developing tiny vetch (Vicia hirsuta [L.] S.F. Gray) seeds. Acta Soc Bot Pol 74(4):287-296

Lahuta LB, Goszczyńska J, Horbowicz M, Hołdyński C, Górecki RJ (2010a) Cyclitols affect accumulation of $\alpha$-Dgalactosides in developing Vicia seeds. Acta Physiol Plant 32:933-942

Lahuta LB, Goszczyńska J, Horbowicz M (2010b) Seed $\alpha$-Dgalactosides of selected Vicia species and enzymes involved in their biosynthesis. Acta Biol Cracov Bot 52(1):27-35

Landry EJ, Fuchs SJ, Hu J (2016) Carbohydrate composition of mature and immature faba bean seeds. J Food Comp Anal 50:55-60

Leht M (2005) Cladistic and phonetic analyses of relationships in Vicia subgenus Cracca (Fabaceae) based on morphological data. Taxon 54(4):1023-1032

Mahalanobis PC (1936) On the generalized distance in statistics. Proc Natl Inst Sci India 12:49-55

Martínez-Villaluenga C, Frias J, Vidal-Valverde C (2008) Alpha-galactosides: antinutritional factors or functional ingredients? Crit Rev Food Sci 48(4):301-316

Martín-Pedrosa M, Varela A, Guillamon E, Cabellos B, Burbano C, Gomez-Fernandez J, de Mercado E, GomezIzquierdo E, Cuadrado C, Muzquiz M (2016) Biochemical characterization of legume seeds as ingredients in animal feed. Spanish J Agric Res. doi:10.5424/sjar/2016141-7450

Merchant A, Richter AA (2011) Polyols as biomarkers and bioindicators for 21 st century plant breeding. Funct Plant Biol 38:934-940

Mikić A, Medović A, Jovanović Ž, Stanisavljević N (2015) A note on the earliest distribution, cultivation and genetic changes in bitter vetch (Vicia ervilia) in ancient Europe. Genetika 47(1):1-11

Muzquiz M, Varela A, Burbano C, Cuadrado C, Guillamon E, Pedrosa MM (2012) Bioactive compounds in legumes: pronutritive and antinutritive actions. Implications for nutrition and health. Phytochem Rev 11:227-244

Muzquiz M, Varela A, Guillamon E, Cabellos B, Burbano C, Gomez-Ferdnandez J, de Mercado E, Gomez-Izquierdo E, Cuadrado C, Pedrosa MM (2015) Biochemical characterization of "minor crops" legume seeds produced for animal feed. In: Antonio M. de Ron (ed) V Meeting AEL ACTAS AEL, vol 6, pp 89-92

Obendorf RL, Górecki RJ (2012) Soluble carbohydrates in legume seeds. Seed Sci Res 22:219-242

Obendorf RL, Zimmerman AD, Ortiz PA, Taylor AG, Schnelby SR (2008) Imbibitonal chilling sensitivity and soluble carbohydrate composition of low raffinose, low stachyose soybean seed. Crop Sci 48:2396-2403

Obendorf RL, Horbowicz M, Lahuta LB (2012) Characterization of sugars, cyclitols and galactosyl cyclitols in seeds by GC. In: Preedy V (ed) Dietary sugars: chemistry, analysis, function and effects. King's College London Royal Society of Chemistry Publishing, London, pp 167-185

Peterbauer T, Richter A (1998) Galactosylononitol and stachyose synthesis in seeds of adzuki bean. Purification and characterization of stachyose synthase. Plant Physiol 117:165-172 
Peterbauer T, Richter A (2001) Biochemistry and physiology of raffinose family oligosaccharides and galactosyl cyclitols in seeds. Seed Sci Res 11:185-197

Peterbauer T, Mach L, Mucha J, Richter A (2002a) Functional expression of cDNA encoding pea (Pisum sativum L.) raffinose synthase, partial purification of the enzyme from maturing seeds, and steady-state kinetic analysis of raffinose synthesis. Planta 215:839-846

Peterbauer T, Mucha J, Mach L, Richter A (2002b) Chain elongation of raffinose in pea seeds. Isolation, characterization, and molecular cloning of a multifunctional enzyme catalyzing the synthesis of stachyose and verbascose. J Biol Chem 277(1):194-200

Peterbauer T, Karner U, Mucha J, Mach L, Jones DA, Hedley CL, Richter A (2003) Enzymatic control of the accumulation of verbascose in pea seeds. Plant Cell Environ 26:1385-1391

Rencher AC (1992) Interpretation of canonical discriminant functions, canonical variates, and principal components. Am Stat 46:217-225

Rolletschek H, Hajirezaei M-R, Wobus U, Weber H (2002) Antisense-inhibition of ADP-glucose pyrophosphorylase in Vicia narbonensis seeds increases soluble sugars and leads to higher water and nitrogen uptake. Planta 214:954-964

Schaefer H, Hechenleitner P, Santos-Guerra A, de Sequeira MM, Pennington RT, Kenicer G, Carine MA (2012) Systematics, biogeography, and character evolution of the legume tribe Fabeae with special focus on the middle-Atlantic island lineages. BMC Evol Biol 12:250
Seidler-Łożykowska K, Bocianowski J (2012) Evaluation of variability of morphological traits of selected caraway (Carum carvi L.) genotypes. Ind Crops Prod 35:140-145

Smýkal P, Coyne CJ, Ambrose MJ, Maxted N, Schaefer H et al (2015) Legume crops phylogeny and genetic diversity for science and breeding. Crit Rev Plant Sci 34(1-3):43-104

Szczeciński P, Gryff-Keller A, Horbowicz M, Lahuta LB (2000) Galactosylpinitols isolated from vetch (Vicia villosa Roth.) seeds. J Agric Food Chem 48:2717-2720

Ueda T, Coseo MP, Harrell TJ, Obendorf RL (2005) A multifunctional galactinol synthase catalyzes the synthesis of fagopyritol A1 and fagopyritol B 1 in buckwheat seed. Plant Sci 168:681-690

Xiaoli X, Liyi Y, Shuang H, Wei L, Yi S, Hao M, Jusong Z, Xiaoxiong Z (2008) Determination of oligosaccharide contents in 19 cultivars of chickpea (Cicer arietinum L.) seeds by high performance liquid chromatography. Food Chem 111:215-219

Yasui T, Ohashi H (1990) The low molecular weight carbohydrate composition of seeds in the Leguminosae-a new taxonomic character in the family. Sci Rep Tohoku Univ (Biol) 4th Ser 39:257-393

Yasui T, Endo Y, Ohashi H (1987) Infrageneric variation of the low molecular weight carbohydrate composition of the seeds of the genus Vicia (Leguminosae). Bot Mag Tokyo 100:255-272

Zalewski K, Lahuta LB (1998) The metabolism of ageing seeds. Changes in the raffinose family oligosaccharides during storage of field bean (Vicia faba var. minor Harz.) seeds. Acta Soc Bot Pol 67(2):193-196 